\title{
Effect of Amino Acids on Secondary Somatic Embryogenesis of Moroccan Cork Oak (Quercus suber L.) Tree
}

\author{
Safaâ Rahmouni 1* ${ }^{*}$ Zineb Nejjar El Ansari' ${ }^{1}$ Alain Badoc ${ }^{2}$, Patrick Martin³, \\ Mohammed L'Bachir El Kbiach'1, Ahmed Lamarti'
}

\author{
${ }^{1}$ Laboratory of Plant Biotechnology, Department of Biology, Faculty of Sciences, Abdelmalek Essaadi University, Tetouan, \\ Morocco \\ ${ }^{2}$ Axe MIB (Molécules d'Intérêt Biologique), Unité de Recherche Enologie, UFR des Sciences Pharmaceutiques, Université de \\ Bordeaux, ISVV (Institut des Sciences de la Vigne et du Vin), Villenave-d'Ornon, France \\ ${ }^{3}$ Université d'Artois, UniLaSalle, Unité Transformations \& Agroressources, Béthune, France
}

Email: *safaarahmouni@hotmail.fr

How to cite this paper: Rahmouni, S., El Ansari, Z.N., Badoc, A., Martin, P., El Kbiach, M.L. and Lamarti, A. (2020) Effect of Amino Acids on Secondary Somatic Embryogenesis of Moroccan Cork Oak (Quercus suber L.) Tree. American Journal of Plant Sciences, 11, 626-641.

https://doi.org/10.4236/ajps.2020.115047

Received: March 19, 2020

Accepted: May 12, 2020

Published: May 15, 2020

Copyright $\odot 2020$ by author(s) and Scientific Research Publishing Inc. This work is licensed under the Creative Commons Attribution International License (CC BY 4.0).

http://creativecommons.org/licenses/by/4.0/

\begin{abstract}
In the present study, we tested the effect of amino acids on secondary somatic embryogenesis of Moroccan cork oak (Quercus suber L.). Secondary mature and immature somatic embryos were obtained from primary somatic embryos cultured in $\mathrm{N}_{30} \mathrm{~K}$ medium supplemented with nineteen amino acids. Stimulation of embryogenesis was dependent on the type and concentration of amino acid in the medium. Thus, L-glutamine and L-asparagine at 3.42 $\mathrm{mM}$ have been proved to be the most favorable for the formation of functional somatic embryos and the induction of secondary somatic embryos.
\end{abstract}

\section{Keywords}

Cork Oak, Quercus suber L., Secondary Somatic Embryogenesis, Amino Acids

\section{Introduction}

Mediterranean forests have been extensively exploited for their different resources. These forests cover 85 million hectares, representing about two percent of the world's forest area (4033 million hectares) [1] and contain more than 25,000 plant species, especially conifers and hardwood species, like oaks [2].

Cork oak (Quercus suber L.), a species belonging to the Fagaceae family, is one of the most characteristic oak species of the Mediterranean ecosystem. It covers 2.2 million hectares of the world forest surface and plays important ecological, economic and social roles. Quercus suber is described for the first time 
by Linnaeus [3] [4]. It belongs to the section Suber of the subgenus Cerris [5]. It is extremely polymorphic, distributed in the Western Mediterranean region, in the various European and African countries and territories: Portugal, Spain, Southern France, Morocco, Algeria, Tunisia, Corsica, Sardinia, Italy and Slovenia [6].

Moroccan cork oak forest covers a total area of 377,000 ha, in the central plateau (2\%), the Atlantic plains (45\%), the Western Rif (35\%), the Taza-Taounate Region (18\%) and that represents $14 \%$ of the total area on the Mediterranean scale [7]. It is an ecosystem of great ecological importance for the conservation of genetic resources and the protection of the environment [8] [9].

Quercus suber is traditionally propagated by acorns [10]. However, acorn production is irregular and highly dependent on climatic conditions [11] and cork oak seeds tend to lose their ability to germinate after a period of storage [10]. For this reason, new techniques of vegetative propagation (like micropropagation) have been used in order to preserve this ecological heritage and to improve some characteristics for agricultural and economic interests [12] [13].

Somatic embryogenesis, a technique of vegetative propagation applied successfully for several other forest species [14] [15], can be used for clonal propagation processes to produce a large number of somatic embryos, from selected trees and in a very short period of time. These embryos can be transformed into identical trees [16].

Secondary somatic embryogenesis allows the formation of new embryos from other somatic embryos. Secondary embryos have multicellular origin and are formed after a slight proliferation of cells in the external layers of the primary embryos cap. Meristematic primordia begin to appear on the periphery of the proliferated tissue and they soon develop into bipolar structures that form cotyledonary primordia. Then, new embryos emerge from the proliferation mass [17].

Composition of medium, culture system and genotype influence embryo multiplication rates and the quality of the newly developed somatic embryos [18]. The presence of cytokinin in the medium induces secondary somatic embryogenesis [19] [20] [21].

Studies on the induction of primary somatic embryogenesis in cork oak and other forest species are numerous [22] [23] [24] [25]. On the other hand, secondary somatic embryogenesis has not been sufficiently studied. Thereby, we established a protocol for secondary somatic embryogenesis of Moroccan cork oak (Quercus suber $\mathrm{L}$.), by testing the effect of nineteen amino acids on the formation and multiplication of secondary embryos from primary somatic embryos.

\section{Material and Methods}

\subsection{Plant Material and Culture Medium}

We used mature somatic embryos that length is $8-12 \mathrm{~mm}$, at cotyledonary stage 
(Figure 1), proliferated from leaves of epicormic shoots; these latter were obtained by cuttings from segments $(30 \mathrm{~cm})$ of branches collected from one more cork oak tree (latitude N 35 $18^{\prime} 520$ and longitude W 005 40'622) of the Bouhachem-Chefchaouen region (Western Rif I2, Morocco) according to the procedure described by Hernandez [26] and Ben Ali [27]. Embryos were multiplied by transplanting every two months on Margara $\left(\mathrm{N}_{30} \mathrm{~K}\right)$ [28] medium using the method described by Ben Ali and Lamarti [29] [30].

\subsection{Influence of Amino Acids on Secondary Somatic Embryogenesis}

Somatic embryos were placed into flasks (two embryos per flask) containing 40 $\mathrm{ml}$ of culture medium containing N30K macronutrients, MS (Murashige and Skoog) [31] micronutrients and vitamins, 0.7\% agar (Bacteriological agar type E) and $100 \mathrm{mg} / \mathrm{l}$ myo-inositol. Different concentrations of L-glutamine (Gln) and L-asparagine (Asn) $(0.03 ; 0.05 ; 0.07 ; 0.1 ; 0.14 ; 0.2 ; 0.27 ; 3.42 ; 3.49$ and $3.56 \mathrm{mM})$ were added to the culture medium. Also, nineteen amino acids were tested at $3.42 \mathrm{mM}$. A medium without amino acids was used as a control.

\subsection{Culture Conditions}

$\mathrm{pH}$ medium was adjusted between 5.6 and 5.8 before autoclaving at $121^{\circ} \mathrm{C}$ for 20 min. However, all amino acids were sterilized by filtration (Filters Millex-Merck Millipore $33 \mathrm{~mm}$ and pore size $0.45 \mu \mathrm{m}$ ) with Durapore membrane (PVDF, ultra-low protein adsorption). Embryos were incubated (without soaking) at $25^{\circ} \mathrm{C} \pm 2{ }^{\circ} \mathrm{C}$ in the dark for two months.

\subsection{Statistical Analysis}

For each condition, two replicates of 24 explants were carried out. After two months of culture, the percentage of functional embryos, the mean number of mature somatic embryos formed on the primary embryo, the mean number of immature somatic embryos formed on the primary embryo and the mean number of total embryos were counted. All results were tested using variance analysis (ANOVA 1) and means were compared using Duncan's multiple range test at $\mathrm{p}$ $<0.05$.
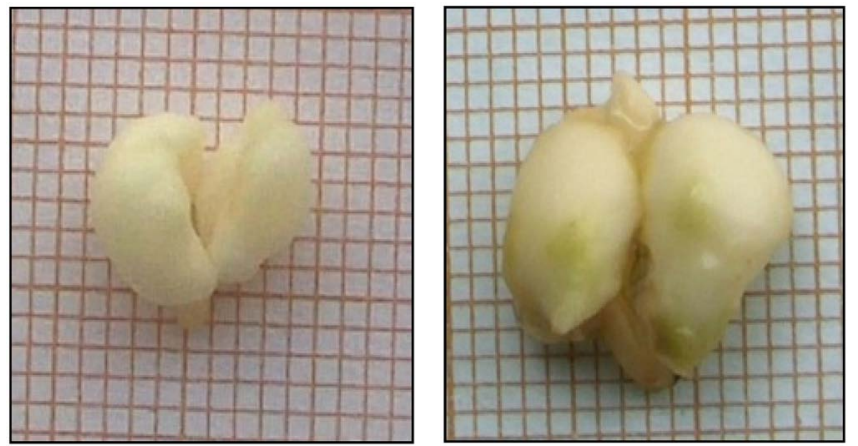

Figure 1. Mature somatic embryos of Quercus suber at cotyledonary stage. 


\section{Results}

\subsection{Effect of L-glutamine and L-asparagine}

After two months of culture, the optimal percentage of functional somatic embryos is observed at $3.42,3.49$ and $3.56 \mathrm{mM}$ of L-glutamine $(79.97 \%, 77.37 \%$ and $76.17 \%$, respectively), followed by L-asparagine at 3.42 and $3.49 \mathrm{mM}(73.16 \%$ and 70.89\%) (Figure 2 and Table 1). Also, the maximum mean number of mature somatic embryos is registered for L-glutamine at $3.42,3.49$ and $3.56 \mathrm{mM}$ (3.90, 3.65 and 3.6 matures $\mathrm{SE}$ /primary SE respectively), followed by L-asparagine at $3.42 \mathrm{mM}$ (3.35 matures SE/primary SE) (Figure 3, Figure 9 and Table 1). Moreover, the highest mean number of immature somatic embryos is recorded in the case of L-glutamine and L-asparagine at $3.42 \mathrm{mM}$ (9.90 and $7.74 \mathrm{imma-}$ ture SE/primary SE, respectively), followed by L-glutamine at $3.49 \mathrm{mM}$ (7.54 immature SE/primary SE respectively) and L-asparagine at $3.49 \mathrm{mM}(7.16 \mathrm{im}$ mature SE/primary SE respectively) (Figure 4, Figure 9 and Table 1). In addition, the maximum mean number of total somatic embryos is obtained in the case of L-glutamine at $3.42 \mathrm{mM}$ (11.5), $3.49 \mathrm{mM}$ (10.1) and $3.56 \mathrm{mM}$ (9.98 SE), followed by L-asparagine at $3.42 \mathrm{mM}$ (9.83 SE) (Figure 5 and Table 1).

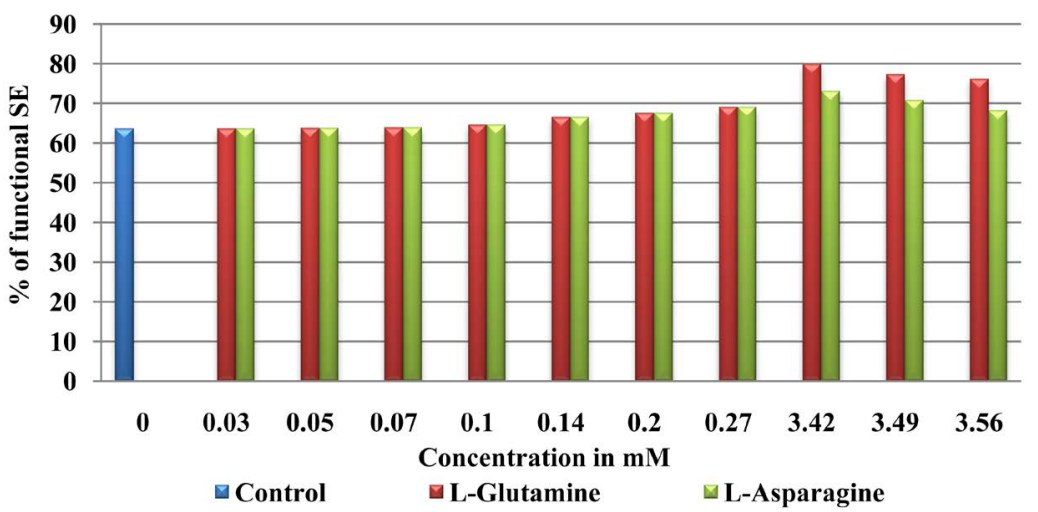

Figure 2. Effect of L-glutamine and L-asparagine at different concentrations on the percentage of functional embryos after 2-month culture in the dark.

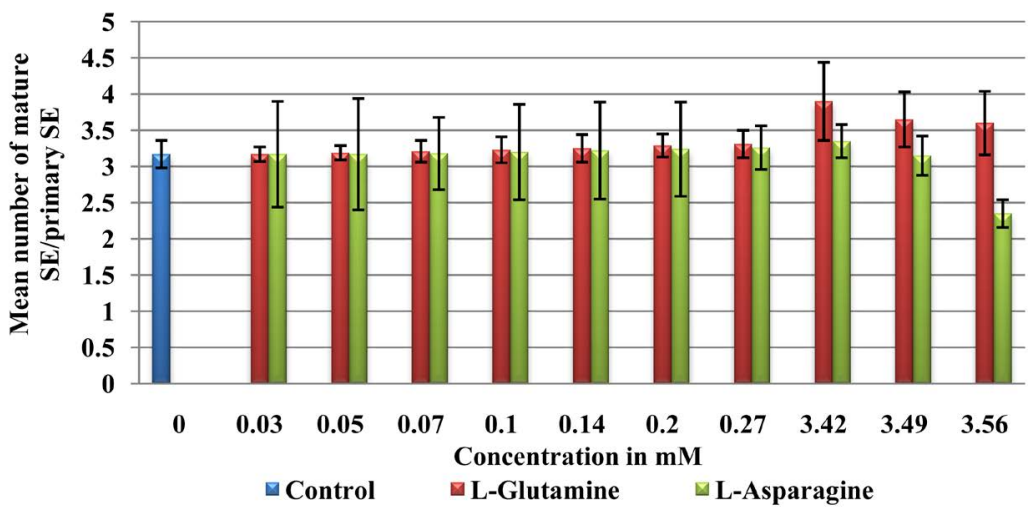

Figure 3. Effect of L-glutamine and L-asparagine at different concentrations on the mean number of mature embryos formed on the primary embryo after 2-month culture in the dark. 


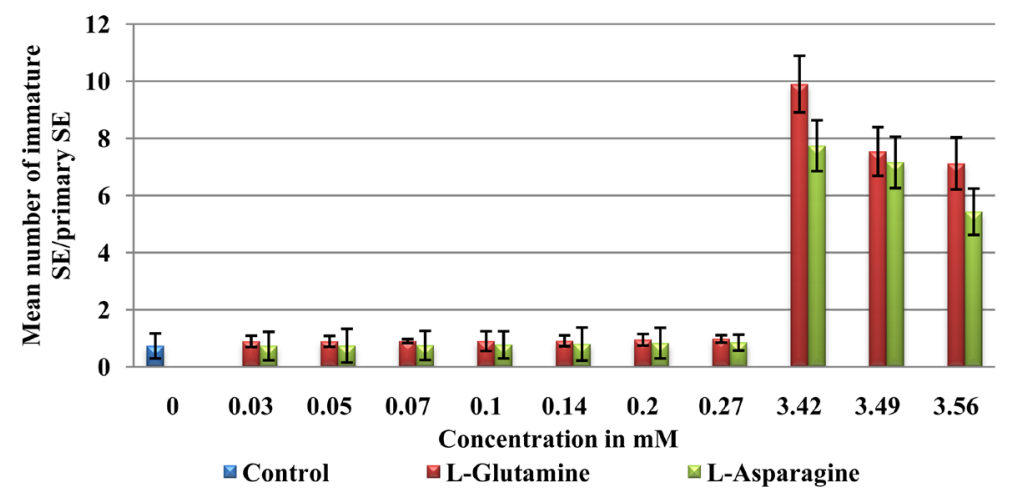

Figure 4. Effect of L-glutamine and L-asparagine at different concentrations on the mean number of immature embryos formed on the primary embryo after 2-month culture in the dark.

Table 1. Effect of L-glutamine and L-asparagine at different concentrations on the percentage of functional embryos, mean number of mature and immature embryos formed on primary somatic embryo and mean number of total embryos. Somatic embryo $=$ SE.

\begin{tabular}{|c|c|c|c|c|c|}
\hline Amino acids & $\begin{array}{l}\text { Concentration } \\
\text { in } \mathrm{mM}\end{array}$ & $\begin{array}{c}\% \text { of } \\
\text { functional } \\
\text { SE }\end{array}$ & $\begin{array}{c}\text { Mean number } \\
\text { of mature } \\
\text { SE/primary SE }\end{array}$ & $\begin{array}{l}\text { Mean number } \\
\text { of immature } \\
\text { SE/primary SE }\end{array}$ & $\begin{array}{c}\text { Mean number } \\
\text { of total } \\
\text { embryos }\end{array}$ \\
\hline \multirow{11}{*}{ L-Glutamine } & 0 & 63.67 & $3.17 \pm 0.19 \mathrm{gh}$ & $0.73 \pm 0.34 \mathrm{i}$ & $3.19 \pm 0.46 \mathrm{j}$ \\
\hline & 0.03 & 63.70 & $3.17 \pm 0.10 \mathrm{gh}$ & $0.89 \pm 0.20 \mathrm{fgh}$ & $3.20 \pm 0.33 \mathrm{ij}$ \\
\hline & 0.05 & 63.82 & $3.19 \pm 0.10 \mathrm{fgh}$ & $0.89 \pm 0.19 \mathrm{fgh}$ & $3.23 \pm 0.34 \mathrm{ij}$ \\
\hline & 0.07 & 63.93 & $3.21 \pm 0.15$ efgh & $0.90 \pm 0.07 \mathrm{fgh}$ & $3.42 \pm 0.25 \mathrm{gh}$ \\
\hline & 0.10 & 64.67 & $3.23 \pm 0.18$ efgh & $0.90 \pm 0.35 \mathrm{fgh}$ & $3.44 \pm 0.81 \mathrm{gh}$ \\
\hline & 0.14 & 66.61 & $3.25 \pm 0.19 \mathrm{defg}$ & $0.91 \pm 0.19 \mathrm{fgh}$ & $3.67 \pm 0.42 \mathrm{f}$ \\
\hline & 0.20 & 67.63 & $3.29 \pm 0.16 \mathrm{cde}$ & $0.95 \pm 0.20 \mathrm{fg}$ & $3.70 \pm 0.29 \mathrm{f}$ \\
\hline & 0.27 & 69.15 & $3.31 \pm 0.19 \mathrm{~cd}$ & $0.98 \pm 0.13 \mathrm{f}$ & $3.73 \pm 0.68 \mathrm{f}$ \\
\hline & 3.42 & 79.97 & $3.90 \pm 0.54 \mathrm{a}$ & $9.90 \pm 0.89 \mathrm{a}$ & $11.50 \pm 1.01 \mathrm{a}$ \\
\hline & 3.49 & 77.37 & $3.65 \pm 0.38 b$ & $7.54 \pm 0.85 \mathrm{c}$ & $10.10 \pm 0.97 \mathrm{~b}$ \\
\hline & 3.56 & 76.17 & $3.60 \pm 0.44 \mathrm{~b}$ & $7.12 \pm 0.91 \mathrm{~d}$ & $9.98 \pm 0.90 \mathrm{~b}$ \\
\hline \multirow{10}{*}{ L-Asparagine } & 0.03 & 63.70 & $3.17 \pm 0.73 \mathrm{gh}$ & $0.73 \pm 0.50 \mathrm{i}$ & $3.20 \pm 0.27 \mathrm{j}$ \\
\hline & 0.05 & 63.82 & $3.17 \pm 0.77 \mathrm{gh}$ & $0.74 \pm 0.59 \mathrm{i}$ & $3.20 \pm 0.40 \mathrm{j}$ \\
\hline & 0.07 & 63.93 & $3.18 \pm 0.50 \mathrm{gh}$ & $0.75 \pm 0.51 \mathrm{i}$ & $3.22 \pm 0.88 \mathrm{ij}$ \\
\hline & 0.10 & 64.67 & $3.20 \pm 0.66 \mathrm{fgh}$ & $0.77 \pm 0.48 \mathrm{hi}$ & $3.31 \pm 0.86 \mathrm{hi}$ \\
\hline & 0.14 & 66.61 & $3.22 \pm 0.67 \mathrm{efgh}$ & $0.80 \pm 0.58 \mathrm{hi}$ & $3.36 \pm 0.91 \mathrm{ghi}$ \\
\hline & 0.20 & 67.63 & $3.24 \pm 0.65 \mathrm{defg}$ & $0.83 \pm 0.54$ ghi & $3.41 \pm 0.94 \mathrm{gh}$ \\
\hline & 0.27 & 69.15 & $3.26 \pm 0.30 \mathrm{def}$ & $0.85 \pm 0.28$ fghi & $3.45 \pm 0.31 \mathrm{~g}$ \\
\hline & 3.42 & 73.16 & $3.35 \pm 0.23 c$ & $7.74 \pm 0.89 b$ & $9.83 \pm 1.00 \mathrm{c}$ \\
\hline & 3.49 & 70.89 & $3.15 \pm 0.27 \mathrm{~h}$ & $7.16 \pm 0.90 \mathrm{~d}$ & $9.17 \pm 1.01 \mathrm{~d}$ \\
\hline & 3.56 & 68.23 & $2.35 \pm 0.19 \mathrm{i}$ & $5.43 \pm 0.81 \mathrm{e}$ & $6.92 \pm 0.99 \mathrm{e}$ \\
\hline
\end{tabular}




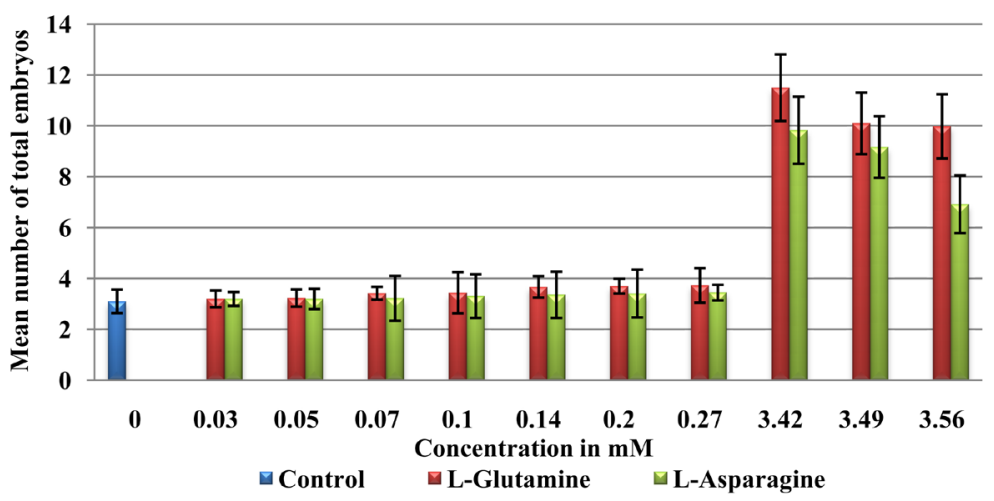

Figure 5. Effect of L-glutamine and L-asparagine at different concentrations on the mean number of total somatic embryos after 2-month culture in the dark.

\subsection{Effect of Amino Acids}

The percentage of functional somatic embryos is optimal in the presence of L-glutamine (79.97\%), followed by L-asparagine (73.16\%), L-ornithine (68.10\%) and L-arginine (65.76\%), on one hand. On the other hand, the minimum percentage (40.54\%) was recorded in the case of L-leucine (Figure 6 and Table 2). Also, the mean number of mature somatic embryos formed on the primary embryo is maximum for L-glutamine (3.9 mature SE/primary SE) and L-asparagine (3.35 mature SE/primary SE). On the other hand, the minimum value (0.59 mature SE/primary SE) is noted for L-cysteine (Figure 7, Figure 9 and Table 2). In addition, a maximum mean number of immature somatic embryos is obtained in the case of L-glutamine (9.9 immature SE/primary SE). The lowest mean number is registered for the control (0.73 immature SE/primary SE) (Figure 8, Figure 9 and Table 2). Moreover, the maximum mean number of total embryos is noticed for L-glutamine (11.5 SE), followed by L-asparagine (9.83 SE) and the minimum for L-cysteine (1.79 SE) (Figure 10 and Table 2).

\section{Discussion}

The induction of secondary somatic embryogenesis from somatic embryos was reported on media containing plant growth regulators [21] [32] [33] and also on a free PGR (Plant Growth Regulators) media [33] [34] [35] [36] [37].

In our study, we tested the effect of amino acids on the process of secondary somatic embryogenesis in Moroccan cork oak primary embryos. Firstly, we tested L-glutamine and L-asparagine at different concentrations and then, nineteen other organic acids at $3.42 \mathrm{mM}$. Induction of embryogenesis and embryo development was strictly dependent on the type and concentration of amino acid in the medium. The best amino acid source was L-glutamine followed by L-asparagine at $3.42 \mathrm{mM}$.

In most cases, the addition of organic nitrogen form (from amino acids) has been mentioned as important factor for somatic embryogenesis, embryo proliferation and maturation and plant conversion [22] [23] [38] [39] [40] [41] [42]. The use of amino acids in herbaceous and conifer species improves embryo 


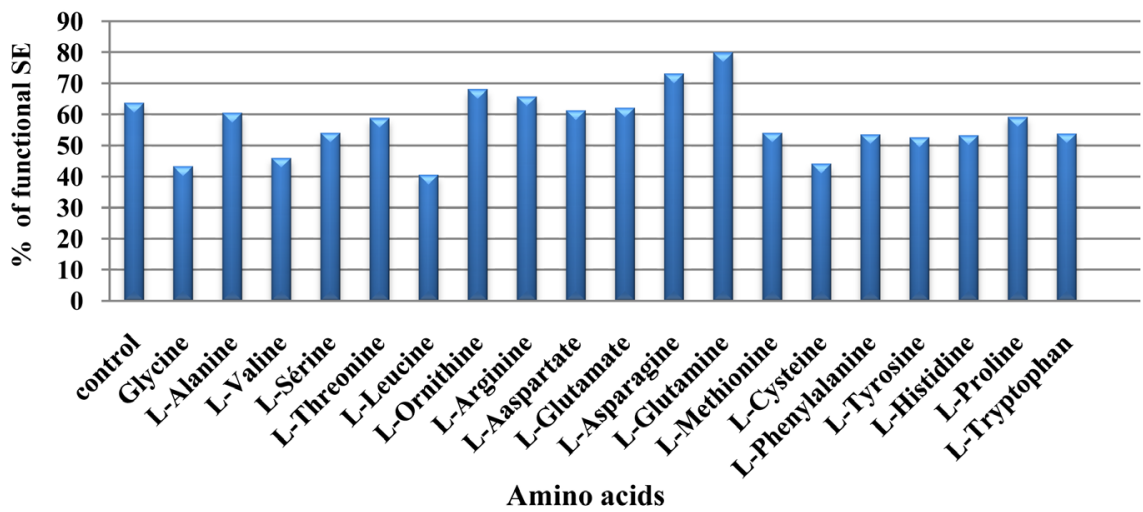

Figure 6. Effect of 19 amino acids at $3.42 \mathrm{mM}$ on the percentage of functional embryos after 2-month culture in the dark.

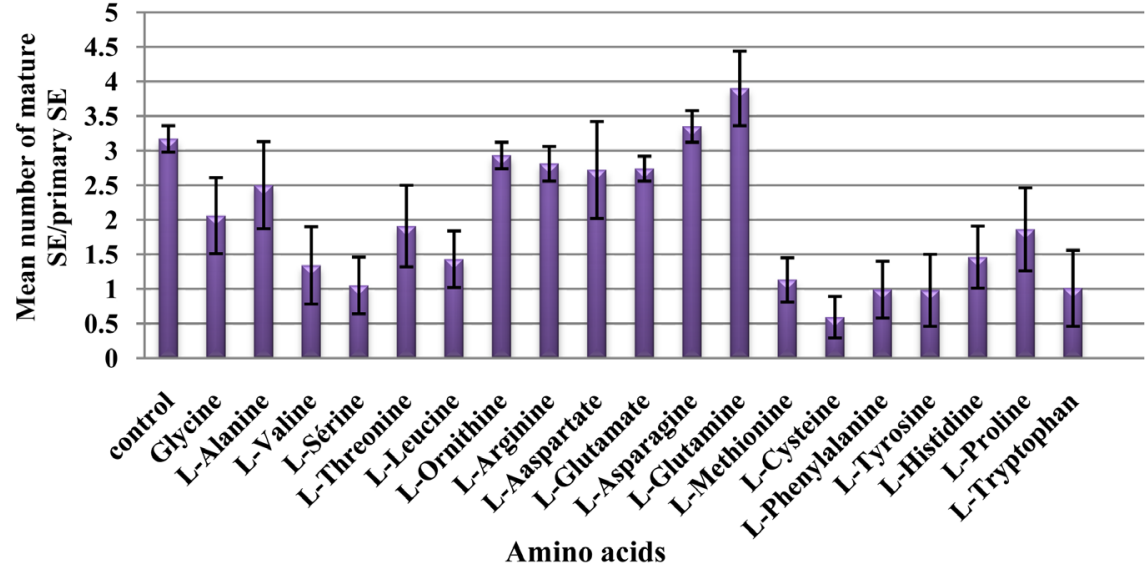

Figure 7. Effect of 19 amino acids at $3.42 \mathrm{mM}$ on the mean number of mature embryos formed on the primary embryo after 2-month culture in the dark.

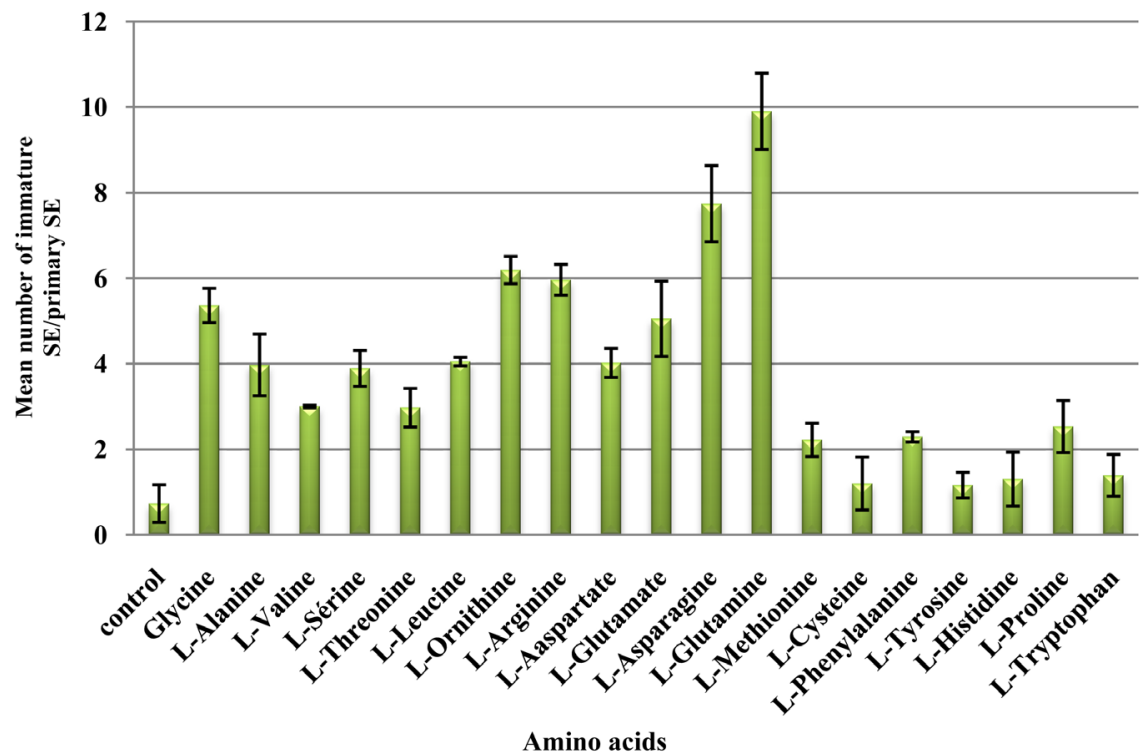

Figure 8. Effect of 19 amino acids at $3.42 \mathrm{mM}$ on the mean number of immature embryos formed on the primary embryo after 2 -month culture in the dark. 


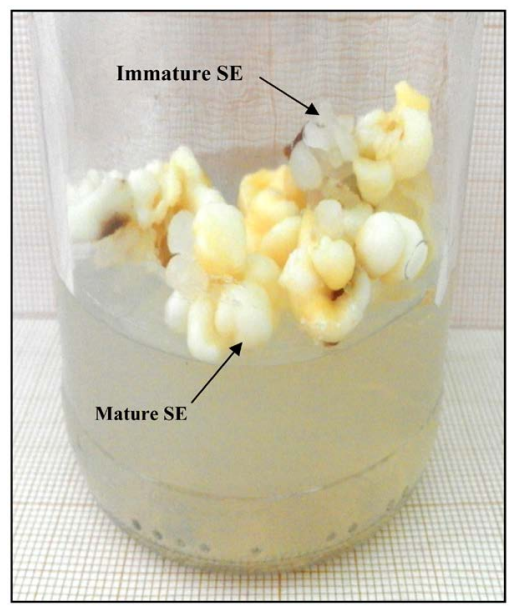

(a)

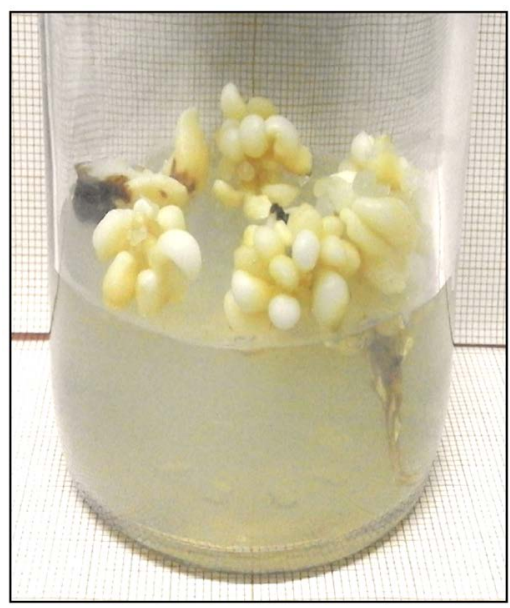

(b)

Figure 9. Aspect of secondary somatic embryos in medium containing $3.42 \mathrm{mM}$ of L-glutamine (a) and L-asparagine (b).

Table 2. Effect of nineteen amino acids at $3.42 \mathrm{mM}$ on the percentage of functional embryos, mean number of mature and immature embryos formed on primary somatic embryo and mean number of total embryos. SE: Somatic embryo.

\begin{tabular}{|c|c|c|c|c|}
\hline Amino acids & $\begin{array}{c}\% \text { of } \\
\text { functional } \\
\text { SE }\end{array}$ & $\begin{array}{c}\text { Mean number } \\
\text { of mature } \\
\text { SE/primary SE }\end{array}$ & $\begin{array}{l}\text { Mean number } \\
\text { of immature } \\
\text { SE/primary SE }\end{array}$ & $\begin{array}{c}\text { Mean number } \\
\text { of total } \\
\text { embryos }\end{array}$ \\
\hline Control & 63.67 & $3.17 \pm 0.19 c$ & $0.73 \pm 0.44 \mathrm{n}$ & $3.10 \pm 0.46 \mathrm{i}$ \\
\hline Glycine & 43.24 & $2.06 \pm 0.55 \mathrm{~g}$ & $5.36 \pm 0.40 \mathrm{e}$ & $4.07 \pm 0.60 \mathrm{f}$ \\
\hline L-Alanine & 60.47 & $2.50 \pm 0.63 \mathrm{f}$ & $3.97 \pm 0.72 \mathrm{gh}$ & $6.47 \pm 0.83 \mathrm{~d}$ \\
\hline L-Valine & 45.95 & $1.34 \pm 0.56 \mathrm{i}$ & $3.00 \pm 0.03 \mathrm{i}$ & $3.92 \pm 0.64 \mathrm{~g}$ \\
\hline L-Serine & 54.05 & $1.05 \pm 0.41 \mathrm{jk}$ & $3.89 \pm 0.42 \mathrm{~h}$ & $4.94 \pm 0.62 \mathrm{e}$ \\
\hline L-Threonine & 58.78 & $1.91 \pm 0.59 \mathrm{~h}$ & $2.97 \pm 0.45 \mathrm{i}$ & $3.88 \pm 0.76 \mathrm{~g}$ \\
\hline L-Leucine & 40.54 & $1.43 \pm 0.41 \mathrm{i}$ & $4.05 \pm 0.10 \mathrm{~g}$ & $3.02 \pm 0.47 \mathrm{i}$ \\
\hline L-Ornithine & 68.10 & $2.93 \pm 0.19 \mathrm{~d}$ & $6.19 \pm 0.32 c$ & $7.33 \pm 0.40 \mathrm{c}$ \\
\hline L-Arginine & 65.76 & $2.81 \pm 0.25 \mathrm{de}$ & $5.96 \pm 0.36 \mathrm{~d}$ & $7.13 \pm 0.47 \mathrm{c}$ \\
\hline L-Aspartate & 61.27 & $2.72 \pm 0.82 \mathrm{e}$ & $4.02 \pm 0.34 \mathrm{~g}$ & $4.12 \pm 0.84 \mathrm{f}$ \\
\hline L-Glutamate & 62.16 & $2.74 \pm 0.18 \mathrm{e}$ & $5.05 \pm 0.88 \mathrm{f}$ & $6.35 \pm 0.98 \mathrm{~d}$ \\
\hline L-Asparagine & 73.16 & $3.35 \pm 0.23 b$ & $7.74 \pm 0.89 \mathrm{~b}$ & $9.83 \pm 0.9 b$ \\
\hline L-Glutamine & 79.97 & $3.90 \pm 0.54 \mathrm{a}$ & $9.90 \pm 0.89 \mathrm{a}$ & $11.50 \pm 0.9 \mathrm{a}$ \\
\hline L-Methionine & 54.05 & $1.13 \pm 0.32 \mathrm{j}$ & $2.22 \pm 0.39 \mathrm{k}$ & $2.92 \pm 0.4 j$ \\
\hline L-Cysteine & 44.12 & $0.59 \pm 0.30 \mathrm{~m}$ & $1.20 \pm 0.62 \mathrm{~lm}$ & $1.79 \pm 0.75 \mathrm{~m}$ \\
\hline L-Phenylalanine & 53.56 & $0.99 \pm 0.41 \mathrm{kl}$ & $1.29 \pm 0.12 \mathrm{~lm}$ & $2.21 \pm 0.571$ \\
\hline L-Tyrosine & 52.56 & $0.98 \pm 0.621$ & $1.16 \pm 0.30 \mathrm{~lm}$ & $2.20 \pm 0.631$ \\
\hline L-Histidine & 53.27 & $1.46 \pm 0.45 \mathrm{i}$ & $1.30 \pm 0.63 \mathrm{~lm}$ & $2.76 \pm 0.85 \mathrm{j}$ \\
\hline L-Proline & 59.12 & $1.86 \pm 0.75 \mathrm{~h}$ & $2.53 \pm 0.61 \mathrm{j}$ & $3.39 \pm 0.99 \mathrm{~h}$ \\
\hline L-Tryptophane & 53.85 & $1.01 \pm 0.55 \mathrm{jkl}$ & $1.39 \pm 0.491$ & $2.53 \pm 0.70 \mathrm{k}$ \\
\hline
\end{tabular}




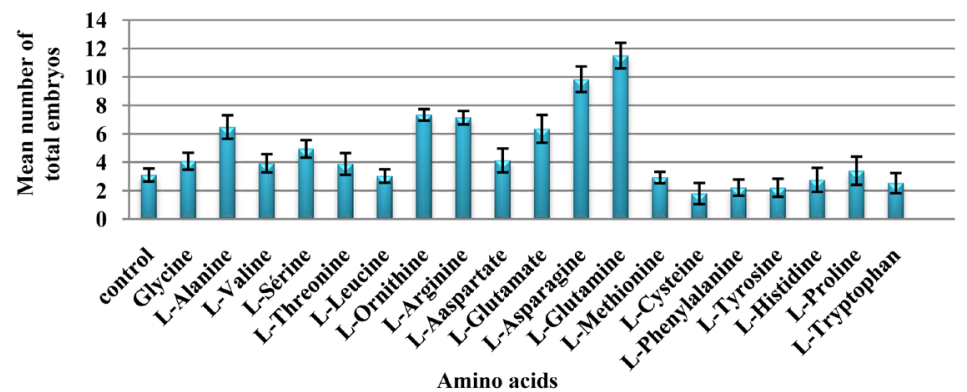

Figure 10. Effect of 19 amino acids at $3.42 \mathrm{mM}$ on the mean number of total embryos after 2-month culture in the dark.

maturation. However, in hardwood species, systematic studies of the effect of organic nitrogen are rare [42].

Glutamine is effective to induce somatic embryogenesis in most studies. This can be due to direct absorption by cells, which leads to lower energy use [43]. Moreover, glutamine is involved in the synthesis of other amino acids and serves as a nitrogen transporter metabolite [42].

Similar to our results, Ara et al. [44] found that the addition of glutamine to the medium induces somatic embryogenesis in Mangifera indica. Also, it was demonstrated that glutamine had a positive effect on growth of Picea abies pro-embryogenic masses [45]. For Sapindus trifoliatus, addition of L-glutamine in the medium influenced influenced the frequency of embryogenesis, induction of nodular embryogenic structures from callus and differentiation of somatic embryos. Maximum results were observed on medium containing $200 \mathrm{mg} / \mathrm{l} \mathrm{glu}-$ tamine [46]. Moreover, Vasanth and Vivier [47] used a medium containing glutamine for proliferation of Vitis vinifera embryo. In Acca sellowiana, the addition of L-glutamine, L-asparagine or arginine improves somatic embryo induction and development [48]. In Cucumis sativus, Ashok and Nurthy [49] studied the effect of amino acids (glutamine, glycine, arginine, asparagine and cysteine) on embryogenesis and plantlet regeneration. They found that the use of induction medium supplemented with a combination of amino acids enhanced both embryo induction and plantlet regeneration. Stuart and Strickland [50] noticed that in Medicago sativa, proline, alanine, glutamine, arginine, lysine, serine, asparagine and ornithine stimulated the number of somatic embryos formed, enhanced their structural quality, increased their size and stimulated embryo conversion.

Rathore et al. [51] reported that L-glutamine stimulated the maturation of Acacia senegal somatic embryos and reduced reduced embryo abnormalities. Rai et al. [52] found that $0.68 \mathrm{mM}$ of glutamine increased maturation percentage of Psidium guajava somatic embryos. Moreover, L-glutamine increased plant conversion and reduced embryo abnormalities in Abelmoschus esculentus [41]. Smith [53] [54] supplemented the maturation medium of Pinus radiata with a solution of seven amino acids, to improve somatic embryos production and plantlet recovery. Khlifi and Tremblay [55] revealed that the maturation of so- 
matic embryos of Picea mariana occurred in a medium supplemented with glutamine as the only source of nitrogen.

Gerdakaneh et al. [40] found that proline, glutamine and alanine were the best amino acids for strawberry embryo culture. Other researchers reported that proline stimulated growth of embryogenic cultures of larch (Larix x leptoeuropaea), sitka spruce (Picea sitchensis) and oak (Quercus robur) in stress conditions [56]. In our case, L-proline showed modest results compared to L-glutamine and $\mathrm{L}$-asparagine on the induction of secondary somatic embryogenesis of Moroccan cork oak.

Also, L-glutamine was used separately or combined with other compounds to promote somatic embryos in Pistacia vera, Phoenix dactylifera, Cullen corylifolium, Colocasia esculenta and Pelargonium sidoides [57] [58] [59] [60] [61]. In Abies alba, embryogenic lines proliferated faster and matured better on a medium containing glutamine and casein hydrolysate [62].

George et al. [63] indicated that the addition of amino acids to media without ammonium ions was beneficial for growth or morphogenesis of cells and tissues. Müller and Grafe [64] cultured Nicotiana tabacum callus on a medium lacking of $\mathrm{NO}_{3}^{-}$and $\mathrm{NH}_{4}^{+}$and supplemented with glycine, arginine, aspartic acid and glutamine. Also, Anderson [65] used glutamine as the only nitrogen source for the growth of wild carrot suspension.

However, Merkle et al. [43] reported that the addition of amino acids to the culture medium might promote or inhibit somatic embryos development and conversion. Pintos et al. [25] studied the effect of amino acids (glutamine, arginine and asparagine) on the growth of cork oak embryos. On the one hand, they showed that the combination of these three amino acids stimulated embryo growth. On the other hand, they noticed that amino acids did not show significant differences with the control. Also, Martinez et al. [66] found that glutamine decreased the number of nodular embryogenic structures and secondary somatic embryos of Quercus ilex. This is contradictory with our results in which we prove the positive effect of L-glutamine and L-asparagine.

Von Arnold [67] found a strong negative effect of L-glutamine, L-arginine, and L-asparagine on the induction of somatic embryogenesis in Picea abies. Changes in the somatic embryo phenotype could be induced by adding amino acid to the medium [68]. Pinto et al. [69] found that the addition of casein hydrolysate and glutamine increased the formation of abnormal embryo in Eucalyptus globulus. Moreover, in Picea glauca, organic nitrogen had a negative effect on somatic embryo maturation [70].

\section{Conclusion}

Secondary somatic embryogenesis is an effective tool for large-scale multiplication of cork oak in particular and for woody plants in general. Thus, the present study is the first one about the effect of amino acids on secondary somatic embryogenesis of cork oak (Quercus suber) from the north of Morocco. 
First, we tested the effect of L-glutamine and L-asparagine at different concentrations and found that the addition of $3.42 \mathrm{mM}$ to the culture medium increases the percentage of functional embryos, the mean number of mature and immature secondary somatic embryos and the mean number of total somatic embryos.

Then, we tested the effect of L-glutamine, L-asparagine and seventeen other amino acids at $3.42 \mathrm{mM}$ and concluded that L-glutamine gives the highest results followed by L-asparagine.

Despite extensive work on somatic embryogenesis, the stage of secondary somatic embryogenesis has been less illustrated and very few studies have focused on optimization of secondary embryo production in oaks.

\section{Acknowledgements}

This work was supported by Hassan II Academy of Sciences and Technology (Morocco). We express our deep gratitude to all forest technicians who contributed to the collection of plant material throughout Morocco.

\section{Conflicts of Interest}

The authors declare no conflicts of interest regarding the publication of this paper.

\section{References}

[1] FAO (2010) Global Forest Resources Assessment. Main Report. FAO Forestry Paper No. 163. Rome.

[2] Myers, N., Mittlemeier, R.A., Mittlemeier, C.G., Da Fonseca, G.A.B. and Kent, J. (2000) Biodiversity Hotspots for Conservation Priorities. Nature, 403, 853-858. https://doi.org/10.1038/35002501

[3] Linnaeus, C. (1753) Species Plantarum, Vol. 1. (Facsimile ed. 2013). The Ray Society, London.

[4] Natividade, J.V. (1956) Subericulture, Edition Française de l'Ouvrage Portugais Subirecultura, Ecole Nationale des Eaux et Forêts (Nancy).

[5] Ceballos, L. and Ruiz de la torre, J. (1979) Árboles y Arbustos de la España Peninsular. Escuela Técnica Superior de Ingenieros de Montes. Madrid, Spain.

[6] Toribio, M., Celestino, C. and Molinas, M. (2005) Cork Oak, Quercus suber L. In: Jain, S.M. and Gupta, P.K., Eds., Protocol of Somatic Embryogenesis in Woody Plants. Forestry Sciences, Volume 77, Springer, Dordrecht, 445-457. https://doi.org/10.1007/1-4020-2985-3_35

[7] Naggar, M. (2014) La Gestion Durable des Subéraies Marocaines : Optimiser la Production des Biens et Services par les Ecosystèmes Boisés Méditerranéens dans un Contexte de Changements Globaux au niveau du Site Pilote de la Forêt de la Maamora (Maroc). Colloque international, VIVexpo, 13 juin.

[8] Eriksson, G., Varela, M.C., Lumaret, R. and Gil, L. (2017) Genetic Conservation and Management of Quercus suber. Technical Bulletin. European Forest Genetic Resources Programme (EUFORGEN), Bioversity International, Rome, Italy.

[9] Capote, T., Usié, A., Barbosa, P., Ramos, M., Morais-Cecilio, L. and Gonçalves, S. 
(2019) Transcriptome Dynamics of Cork Oak (Quercus suber) Somatic Embryogenesis Reveals Active Gene Players in Transcription Regulation and Phytohormone Homeostasis of Embryo Development. Tree Genetics \& Genomes, 15, 52. https://doi.org/10.1007/s11295-019-1353-6

[10] Chalupa, V. (1995) Somatic Embryogenesis in Oak (Quercus spp.) In: Jain, S.M., Gupta, P.K. and Newton, R.J., Eds., Somatic Embryogenesis in Woody Plants. Forestry Sciences, Volume 2, Springer, Dordrecht, 67-87.

https://doi.org/10.1007/978-94-011-0491-3_5

[11] Bueno, M.A., Gómez, A. and Manzanera, J.A. (2000) Somatic and Gametic Embryogenesis in Quercus suber L. In: Gupta, P.K., Jain, S.M. and Newton, R.J., Eds., Somatic Embryogenesis in Woody Plants, Volume 6, Kluwer Academic Publishers, Netherlands, 479-507. https://doi.org/10.1007/978-94-017-3030-3_16

[12] Komamine, A., Matsumoto, M., Tsukahara, M., Fujiwara, A., Kawahara, R., Ito, M., Smith, J., Nomura, K. and Fujimura, T. (1992) Mechanisms of Somatic Embryogenesis in Cell Cultures: Physiology, Biochemistry and Molecular Biology. In Vitro Cellular \& Developmental Biology, 28, 11-14. https://doi.org/10.1007/BF02632185

[13] Savill, P.S. and Kanowski, P.J. (1993) Tree Improvement Programs for European Oaks: Goals and Strategies. Annales des Sciences Forestières, 50, 368-383. https://doi.org/10.1051/forest:19930741

[14] Thorpe, T.A., Harry, I.S. and Kumar, P.P. (1991) Application of Micropropagation to Forestry. In: Debergh, P.C. and Zimmerman, R.H., Eds., Micropropagation, Technology and Application, Kluwer Academic, Dordrecht, 311-336. https://doi.org/10.1007/978-94-009-2075-0_21

[15] Dunstan, D.I., Tautorus, T.U. and Thorpe, T.A. (1995) Somatic Embryogenesis in Woody Plants. In: Thorpe, T.A., Ed., In Vitro Embryogenesis in Plants, Springer, Netherlands, 471-538. https://doi.org/10.1007/978-94-011-0485-2_12

[16] Canhoto, J.M. (2010) Biotecnologia Vegetal da Clonagem de Plantas à Transformação Genética. Imprensa da Universidade de Coimbra/Coimbra University Press, Coimbra. https://doi.org/10.14195/978-989-26-0404-6

[17] Puigderrajols, P., Fernandez-Guijarro, B., Toribio, M. and Molinas, M. (1996) Origin and Early Development of Secondary Embryos in Quercus suber L. International Journal of Plant Sciences, 157, 674-684. https://doi.org/10.1086/297389

[18] Corredoira, E., Toribio, M. and Vieitez, A.M. (2014) Clonal Propagation via Somatic Embryogenesis in Quercus spp. In: Ramawhat, K.G., Mérillon, J.M. and Ahuja, M.R., Eds., Tree Biotechnology, CRC Press, Boca Raton, FL, 262-302. https://doi.org/10.1201/b16714-13

[19] Cuenca, B., San-José, M.C., Martínez, M.T., Ballester, A. and Vieitez, A.M. (1999) Somatic Embryogenesis from Stem and Leaf Explants of Quercus robur L. Plant Cell Reports, 18, 538-543. https://doi.org/10.1007/s002990050618

[20] Wilhelm, E. (2000) Somatic Embryogenesis in Oak (Quercus spp.). In Vitro Cellular \& Developmental Biology-Plant, 36, 349-357. https://doi.org/10.1007/s11627-000-0062-y

[21] Mallón, R., Martínez, T., Corredoira, E. and Vieitez, A.M. (2013) The Positive Effect of Arabinogalactan on Induction of Somatic Embryogenesis in Quercus bicolor Followed by Embryo Maturation and Plant Regeneration. Trees, 27, 1285-1296. https://doi.org/10.1007/s00468-013-0877-x

[22] Testillano, P.S., Gómez-Garay, A., Pintos, B. and Risueño, M.C. (2018) Somatic Embryogenesis of Quercus suber L. from Immature Zygotic Embryos. In: Loyola-Vargas, V. and Ochoa-Alejo, N., Eds., Plant Cell Culture Protocols. Methods in 
Molecular Biology, Humana Press, New York, 247-256.

https://doi.org/10.1007/978-1-4939-8594-4_16

[23] Testillano, P.S., Pintos, B., Gomez-Garay, A. and Risueño, M.C. (2018) Stress-Induced Microspore Embryogenesis by Anther Culture of Quercus suber L. In: Jain, S. and Gupta, P., Eds., Step Wise Protocols for Somatic Embryogenesis of Important Woody Plants. Forestry Sciences, Volume 84, Springer, Cham, 93-105. https://doi.org/10.1007/978-3-319-89483-6_7

[24] Jiménez, J., López-Vela, D., Ruiz-Galea, M., Celestino, C., Toribio, M. and Alegre, J. (2013) Embryogenic Suspensions of Adult Cork Oak: the First Step towards Mass Propagation. Trees, 27, 13-23. https://doi.org/10.1007/s00468-012-0763-y

[25] Pintos, B., Manzanera, J.A. and Bueno, M.A. (2010). Oak Somatic and Gametic Embryos Maturation Is Affected by Charcoal and Specific Aminoacids Mixture. Annals of Forest Science, 67, 205. https://doi.org/10.1051/forest/2009098

[26] Hernández Sánchez, I. (2007) Regeneración Clonal de Alcornoques Adultos (Quercus suber L.) Mediante Embriogénesis Somática. Tesis Doctoral (215 páginas), Universidad de Alcalà, Madrid (España).

[27] Ben Ali, N. (2014) Induction d'Embryogenèse Somatique Directe sur des Limbes Issus de Boutures Débourrées d'Arbres Plus de Chêne liège (Quercus suber L., Fagaceae) de Trois Subéraies (Aïn Rami, Bouhachem et Maâmora). Thèse de Doctorat (169 p.) de l'Université Abdelmalek Essaâdi, Tétouan (Maroc).

[28] Margara, J. (1978) Mise au Point d'une Gamme de Milieux Minéraux pour les Conditions de la Culture in Vitro. Compte Rendu de I Académie d Agriculture de France, 8, 651-661.

[29] Ben Ali, N. and Lamarti, A. (2013) Effect of Carbon Source on Secondary Somatic Embryogenesis of Moroccan Cork Oak (Quercus suber L.). ScienceLib Editions Mersenne. https://doi.org/10.4236/ajps.2014.513199

[30] Ben Ali, N. and Lamarti, A. (2014). Macronutrients Effect on Secondary Somatic Embryogenesis of Moroccan Cork Oak (Quercus suber L.). American Journal of Plant Sciences, 5, 1851-1861. https://doi.org/10.4236/ajps.2014.513199

[31] Murashige, T. and Skoog, F. (1962) A Revised Medium for Rapid Growth and Bioassays with Tobacco Tissue Culture. Physiologia Plantarum, 15, 473-497. https://doi.org/10.1111/j.1399-3054.1962.tb08052.x

[32] Valladares, S., Sánchez, C., Martínez, M.T., Ballester, A. and Vieitez, A.M. (2006) Plant Regeneration through Somatic Embryogenesis from Tissues of Mature Oak Trees: True-to-Type Conformity of Plantlets by RAPD Analysis. Plant Cell Reports, 25, 879-886. https://doi.org/10.1007/s00299-005-0108-Z

[33] Zdravković-Korac, S., Ćalić-Dragosavac, D., Uzelac, B., Janošević, D., Budimir, S., Vinterhalter, B. and Vinterhalter, D. (2008) Secondary Somatic Embryogenesis versus Caulogenesis from Somatic Embryos of Aesculus carnea Hayne.: Developmental Stage Impact. Plant Cell, Tissue and Organ Culture, 94, 225-231. https://doi.org/10.1007/s11240-008-9399-4

[34] El Maâtaoui, M., Espagnac, H. and Michaux-Ferrière, N. (1990) Histology of Callogenesis and Somatic Embryogenesis Induced in Stem Fragments of Cork Oak (Quercus suber) Cultured in Vitro. Annals of Botany, 66, 183-190. https://doi.org/10.1093/oxfordjournals.aob.a088014

[35] Fernández-Guijarro, B., Celestino, C. and Toribio, M. (1995) Influence of External Factors on Secondary Embryogenesis and Germination in Somatic Embryos from Leaves of Quercus suber L. Plant Cell, Tissue and Organ Culture, 41, 99-106. https://doi.org/10.1007/BF00051578 
[36] Puigderrajols, P., Celestino, C., Suils, M., Toribio, M. and Molinas, M. (2000) Histology of Organogenic and Embryogenic Responses in Cotyledons of Somatic Embryos of Quercus suber L. International Journal of Plant Sciences, 161, 353-362. https://doi.org/10.1086/314266

[37] Ćalić, D., Zdravković-Korać, S. and Radojević, L. (2005) Secondary Embryogenesis in Androgenic Embryo Cultures of Aesculus hippocastanum L. Biologia Plantarum, 49, 435-438. https://doi.org/10.1007/s10535-005-0023-8

[38] Robichaud, R.L., Lessard, V.C. and Merkle, S.A. (2004) Treatments Affecting Maturation and Germination of American Chestnut Somatic Embryos. Journal of Plant Physiology, 161, 957-969. https://doi.org/10.1016/j.jplph.2004.03.003

[39] Zouine, J. and El Hadrami, I. (2007) Effect of 2,4-D, Glutamine, and BAP on Embryogenic Suspension Culture of Date Palm (Phoenix dactylifera L.). Scientia Horticulturae, 112, 221-226. https://doi.org/10.1016/j.scienta.2006.12.041

[40] Gerdakaneh, M., Mozafari, A.A. and Sarabi, B. (2011) Effects of Different Amino Acids on Somatic Embryogenesis of Strawberry (Fragaria $\times$ ananassa Duch.). Acta Physiologiae Plantarum, 33, 1847-1852. https://doi.org/10.1007/s11738-011-0725-9

[41] Daniel, M.A., Host Antony David, R., Antony Caesar, S., Ramakrishnan, M., Duraipandiyan, V., Ignacimuthu, S. and Al-Dhabi, N.A. (2018) Effect of L-Glutamine and Casein Hydrolysate in the Development of Somatic Embryos from Cotyledonary Leaf Explants in Okra (Abelmoschus esculentus L. Monech). South African Journal of Botany, 114, 223-231. https://doi.org/10.1016/j.sajb.2017.11.014

[42] Corredoira, E., Merkle, S.A., Martínez, M.T., Toribio, M., Canhoto, J.M., Correia, S.I., Ballester, A. and Vieitez, A.M. (2019) Non-Zygotic Embryogenesis in Hardwood Species. Critical Reviews in Plant Sciences, 38, 29-97. https://doi.org/10.1080/07352689.2018.1551122

[43] Merkle, S.A., Parrott, W.A. and Flinn, B.S. (1995) Morphogenic Aspects of Somatic Embryogenesis. In: Thorpe, T.A., Ed., In Vitro Embryogenesis in Plants, Springer, Dordrecht, 155-203. https://doi.org/10.1007/978-94-011-0485-2_5

[44] Ara, H., Jaiswal, U. and Jaiswal, V.S. (2005) Mango (Mangifera indica L.). In: Jain, S.M. and Gupta, P.K., Eds., Protocol for Somatic Embryogenesis in Woody Plants. Forestry Sciences, Springer, Dordrecht, 229-246. https://doi.org/10.1007/1-4020-2985-3_18

[45] Carlson, J., Svennerstam, H., Moritz, T., Egertsdotter, U. and Ganeteg U. (2017) Nitrogen Uptake and Assimilation in Proliferating Embryogenic Cultures of Norway Spruce-Investigating the Specific Role of Glutamine. PLOS ONE, 12, 1-18. https://doi.org/10.1371/journal.pone.0181785

[46] Asthana, P., Rai, M.K. and Jaiswal, U. (2017) Somatic Embryogenesis from Sepal Explants in Sapindus trifoliatus, a Plant Valuable in Herbal Soap Industry. Industrial Crops and Products, 100, 228-235. https://doi.org/10.1016/j.indcrop.2017.02.034

[47] Vasanth, K. and Vivier, M.A. (2011) Improved Cryopreservation Procedure for Long Term Storage of Synchronised Culture of Grapevine. Biologia Plantarum, 55, 365-369. https://doi.org/10.1007/s10535-011-0056-0

[48] Dal Vesco, L.L. and Guerra, M.P. (2001) The Effectiveness of Nitrogen Sources in Feijoa Somatic Embryogenesis. Plant Cell, Tissue and Organ Culture, 64, 19-25. https://doi.org/10.1023/A:1010635926146

[49] Ashok Kumar, H.G. and Murthy, H.N. (2004) Effects of Sugars and Amino Acids on Androgenesis of Cucumis sativus L. Plant Cell, Tissue and Organ Culture, 78, 201-208. https://doi.org/10.1023/B:TICU.0000025637.56693.68

[50] Stuart, D.A. and Strickland, S.G. (1984) Somatic Embryogenesis from Cell Cultures 
of Medicago sativa L. I. the Role of Amino Acid Additions to the Regeneration Medium. Plant Science Letters, 34, 165-174. https://doi.org/10.1016/0304-4211(84)90139-1

[51] Rathore, J., Rai, M.K. and Shekhawat, N.S. (2012) Induction of Somatic Embryogenesis in Gum Arabic Tree [Acacia senegal (L.) Willd.]. Physiology and Molecular Biology of Plants, 18, 387-392. https://doi.org/10.1007/s12298-012-0130-x

[52] Rai, M.K., Jaiswal, V.S. and Jaiswal, U. (2009) Effect of Selected Amino Acids and Polyethylene Glycol on Maturation and Germination of Somatic Embryos of Guava (Psidium guajava L.). Scientia Horticulturae, 121, 233-236. https://doi.org/10.1016/j.scienta.2009.01.022

[53] Smith, D.R. (1994) Growth Medium for Plant Embryogenic Tissue. Australia Canada Patent No. PM5232.

[54] Smith, D. R. (1997) The Role of in Vitro Methods in Pine Plantation Establishment: the Lesson from New Zealand. Plant Tissue Culture and Biotechnology, 3, 63-73. https://doi.org/10.1023/A:1005893814507

[55] Khlifi, S. and Tremblay, F.M. (1995) Maturation of Black Spruce Somatic Embryos. Part I. Effect of L-Glutamine on the Number and Germinability of Somatic Embryos. Plant Cell, Tissue and Organ Culture, 41, 23-32. https://doi.org/10.1007/BF00124083

[56] Gleeson, D., Lelu-Walter, M.A. and Parkinson, M. (2004) Influence of Exogenous L-Proline on Embryogenic Cultures of Larch (Larix leptoeuropaea Dengler), Sitka Spruce (Picea sitchensis (Bong.) Carr.) and Oak (Quercus robur L.) Subjected to Cold and Salt Stress. Annals of Forest Science, 61, 125-128. https://doi.org/10.1051/forest:2004003

[57] Baskaran, P. and Jayabalan N. (2009) In Vitro Propagation of Psoralea corylifolia L. by Somatic Embryogenesis in Cell Suspension Culture. Acta Physiologiae Plantarum, 31, 1119-1127. https://doi.org/10.1007/s11738-009-0330-3

[58] Deo, P.C., Taylor, M., Harding, R.M., Tyagi, A.P. and Becker, D.K. (2010) Initiation of Embryogenic Cell Suspensions of Taro (Colocasia esculenta var. esculenta) and Plant Regeneration. Plant Cell, Tissue and Organ Culture, 100, 283-291. https://doi.org/10.1007/s11240-009-9648-1

[59] Ageel, S. and Elmeer, K. (2011) Effects of Casein Hydrolysates and Glutamine on Callus and Somatic Embryogenesis of Date Palm (Phoenix dactylifera L.). New York Science Journal, 4, 121-125. http://www.sciencepub.net/newyork

[60] Kumar, V., Moyo, M. and Van Staden, J. (2015) Somatic Embryogenesis of Pelargonium sidoides DC. Plant Cell, Tissue and Organ Culture, 121, 571-577. https://doi.org/10.1007/s11240-015-0726-2

[61] Ghadirzadeh-Khorzoghi, E., Jahanbakhshian-Davaran, Z. and Seyedi, S.M. (2019) Direct Somatic Embryogenesis of Drought Resistance Pistachio (Pistacia vera L.) and Expression Analysis of Somatic Embryogenesis-Related Genes. South African Journal of Botany, 121, 558-567. https://doi.org/10.1016/j.sajb.2019.01.023

[62] Hristoforoglu, K., Schmidt, J. and Bolhar-Nordenkampf, H. (1995) Development and Germination of Abies alba Somatic Embryos. Plant Cell, Tissue and Organ Culture, 40, 277-284. https://doi.org/10.1007/BF00048134

[63] George, E.F., Hall, M.A. and Klerk, G. (2008) The Components of Plant Tissue Culture Media I: Macro- and Micro-Nutrients. In: Plant Propagation by Tissue Culture, Springer, Dordrecht, 65-113. https://doi.org/10.1007/978-1-4020-5005-3_3

[64] Müller, A.J. and Grafe, R. (1978) Isolation and Characterization of Cell Lines of Nicotiana tabacum Lacking Nitrate Reductase. Molecular and General Genetics, 161, 
67-76. https://doi.org/10.1007/BF00266616

[65] Anderson, J.O. (1976) Embryogenesis in Wild Carrot Cells. In: George, E.F., Hall, M. and Klerk, G., Eds., Plant Propagation by Tissue Culture, The Background, Springer, Berlin, 332

[66] Martínez, M.T., San José, M.C., Vieitez, A.M., Cernadas, M.J., Ballester, A. and Corredoira, E. (2017) Propagation of Mature Quercus ilex L. (Holm Oak) Trees by Somatic Embryogenesis. Plant Cell, Tissue and Organ Culture, 131, 321-333. https://doi.org/10.1007/s11240-017-1286-4

[67] Von Arnold, S. (1987) Improved Efficiency of Somatic Embryogenesis in Mature Embryos of Picea abies (L.) Karst. Journal of Plant Physiology, 128, 233-244. https://doi.org/10.1016/S0176-1617(87)80237-7

[68] Zavattieri, M.A., Frederico, A.M. and Lima, M. (2010) Induction of Somatic Embryogenesis as an Example of Stress-Related Plant Reactions. Electronic Journal of Biotechnology, 13, 12-13. https://doi.org/10.2225/vol13-issue1-fulltext-4

[69] Pinto, G., Valentim, H., Costa, A., Castro, S. and Santos, C. (2002) Somatic Embryogenesis in Leaf Callus from a Mature Quercus suber L. Tree. In Vitro Cellular \& Developmental Biology-Plant, 38, 569-572. https://doi.org/10.1079/IVP2002352

[70] Barrett, J.D., Park, Y.S. and Bonga, J.M. (1997) The Effectiveness of Various Nitrogen Sources in White Spruce [Picea glauca (Moench) Voss] Somatic Embryogenesis. Plant Cell Reports, 16, 411-415. https://doi.org/10.1007/s002990050250 